\title{
PEMANFAATAN PERPUSTAKAAN SEKOLAH SEBAGAI SUMBER BELAJAR BAHASA INDONESIA DI SD NEGERI KRANDON 1 TEGAL
}

\author{
Sri Mulyati ${ }^{1}$; Yulia Prima Sari ${ }^{2}$; Wahyu Asriyani ${ }^{3}$; Muhammad Rasyid Ridlo ${ }^{4}$; Yoandini Saputri ${ }^{5}$. \\ ${ }^{1,2,3}$ Universitas Pancasakti Tegal \\ ${ }^{4,5}$ Universitas Sumatera Utara
}

\begin{abstract}
ABSTRAK:
Perpustakaan SD Negeri Krandon 1 Tegal sangat aktif dalam memberikan perhatian dan kepedulian terhadap optimalisasi kegiatan pembelajaran di sekolah.Perpustakaan sekolah di SD Negeri Krandon 1 Tegal tersebut sudah cukup baik dalam menunjang pembelajaran Bahasa Indonesia, hal itu dapat dilihat banyaknya peminjaman buku Kesusastraan dan Bahasa Indonesia pada bulan Juli - September. Penelitian ini menggunakan jenis penelitian hukum empiris dengan pendekatan kualitatif. Pengambilan sumber data penelitian ini menggunakan teknik "purpossive sampling" dengan subjek yang diteliti adalah siswa kelas 3, 4, 5, dan 6 yang karena cara pikir dan kematangan psikologis mereka sudah lebih baik dalam dengan tujuan untuk menghilangkan kemungkinan terjadinya "kemencengan" (bias). Sedangkan objeknya adalah kegiatan-kegiatan yang dilakukan di perpustakaan dalam rangka pemanfaatan Perpustakaan Sekolah SD Negeri Krandon 1 Tegal sebagai penunjang kegiatan belajarmengajar terutama mata pelajaran Bahasa Indonesia. Selain mewawancarai para siswa, peneliti juga mewawancarai pihakpihak internal sekolah, serta mewawancarai ahli/pakar di dunia Bidang Ilmu Pendidikan dan Pakar Ilmu Perpustakaan terkait dengan Pemanfaatan Perpustakaan Sekolah sebagai Sumber Belajar Bahasa Indonesia. Berdasarkan hasil penelitian serta menganalisis data-data yang diperoleh maka dapat disimpulkan bahwa perpustakaan di SD Negeri Krandon 1 Tegal sangat baik dalam menunjang pembelajaran Bahasa Indonesia, dari segi sarana dan prasarana sudah memenuhi standar perpustakaan hanya ada beberapa sarana yang kurang lengkap.
\end{abstract}

\section{Kata kunci: Pemanfaatan Perpustakaan sekolah; Sumber belajar; bahasa Indonesia.}

\begin{abstract}
:
Krandon 1 Tegal ELEMENTARY School Library is very active in giving attention and concern to the optimization of learning activities in schools. School library in SD Krandon 1 Tegal is good enough in support of Indonesian language, it is a very Dilihatsmany of the languages and language Indonesia pada bulan Juli-September.This research uses the type of empirical legal research with a qualitative approach. The retrieval of this research data source using the "purpossive sampling" technique with subjects studied were students of grades 3, 4, 5, and 6 who because of their way of thinking and psychological maturity were better in order to eliminate the possibility of "frankeness" (bias). While the object is activities conducted in the library in the framework of the utilization of the school library Krandon SD 1 Tegal as a supporting learning activities especially Indonesian subjects. In addition to interviewing the students, researchers also interviewed internal school parties, as well as interviewed experts in the World of Education science and Library science experts related to the utilization of the school library as a source of learning Bahasa Indonesia. Based on the research and analysis of the data obtained it can be concluded that the library in SD Negeri Krandon 1 Tegal is very good in supporting Bahasa Indonesia, in terms of facilities and infrastructure already meet the standard library there are only a few tools that are less complete. The Indonesian book references in SD Krandon 1 Tegal are also very complete, making it easy for learners to work on or complete assignments given by the teacher. Krandon State Elementary School 1 Tegal is quite good as a source of learning, seen from the facilities and infrastructures.
\end{abstract}

Keyword:Utilization of School Library;Learning Resources;Indonesian 


\section{Sri Mulyati, Yuliana Purma Sari, Wahyu Asriyani, Muhammad Rasyid Ridho, Yoandini Saputri}

Pemanfaatan Perpustakaan Sekolah Sebagai Sumber Belajar Bahasa Indonesia

\section{PENDAHULUAN}

Perkembangan ilmu pengetahuan dan teknologi memberi pengaruh besar dalam berbagai bidang khususnya bidang pendidikan.Pengaruh tersebut memberikan banyak perubahan pada semua tingkat dan jenjang pendidikan yang meliputi pada struktur pendidikan, metode mengajar, disiplin ilmu serta kebijakan-kebijakan dalam dunia pendidikan.

Menurut Undang-undang Sistem Pendidikan Nasional Nomor 20 Tahun 2003 disebutkan bahwa, pendidikan merupakan usaha sadar dan terencana untuk mewujudkan suasana belajar dan proses pembelajaran agar peserta didik secara aktif mengembangkan potensi dirinya untuk memiliki kekuatan spiritual keagamaan, pengendalian diri, kepribadian, kecerdasan, akhlak mulia, serta ketrampilan yang diperlukan dirinya dalam hidup bermasyarakat.

Sekolah sebagai lembaga pendidikan yang melaksanakan kegiatan belajar dan pengajaran dituntut untuk menghasilkan sumber daya manusia yang berkualitas.Keberhasilan pendidikan di sekolah dapat dicapai jika seluruh komponen pendukung seperti kepala sekolah, guru, siswa, kurikulum, metode pengajaran, serta sarana-prasarana penunjang kegiatan belajar mengajar dapat saling mempengaruhi dan mendukung upaya pencapaian tujuanpendidikan.

Salah satu sarana penunjang kegiatan belajar mengajar di sekolah adalah perpustakaan.Dengan diadakannya perpustakaan dapat memungkinkan para tenaga pendidik dan peserta didik memperoleh kesempatan untuk memperluas dan memperdalam pengetahuan dengan membaca bahan pustaka yang mengandung ilmu pengetahuan.Melalui perpustakaan para siswa diharapkan dapat memperoleh ilmu pengetahuan tanpa harus menunggu para guru memberikan informasi terlebihdahulu.
SD Negeri Krandon 1 Tegal merupakan Sekolah Rintisan Bertaraf Nasional (RSBN) yang menggunakan sistem Kurikulum 2013 (Kurtilas) dimana sistem pengajaran dibagi menjadi beberapa tema.Setiap tema mengandung beberapa pelajaran seperti Matematika, IPA, dan Bahasa Indonesia. Perangkat pembelajaran lain seperti kalender pendidikan, serta silabus dan lesson plan (Rencana Program Pembelajaran/RPP) juga disertakan dalam setiap kegiatan belajar dan mengajar.

Perpustakaan SD Negeri Krandon 1 Tegal sangat aktif dalam memberikan perhatian dan kepedulian terhadap optimalisasi kegiatan pembelajaran di sekolah.Perpustakaan ini didirikan untuk menunjang tercapainya tujuan pendidikan, khususnya dalam menyediakan informasi yang berguna dalam keberlangsungan kegiatan belajarmengajar di sekolah.Bahasa Indonesia di SDN Krandon 1 Tegal.

Para guru di SD Negeri Krandon 1 Tegal memiliki sebuah silabus dan lesson plan (Rencana Program Pembelajaran/RPP) untuk mendukung kelancaran kegiatan belajar- mengajar. Silabus adalah rencana pembelajaran pada suatu dan atau kelompok mata pelajaran/tema tertentu yang mencakup standar kompetensi, kompetensi dasar, materi pokok/pembelajaran, kegiatan pembelajaran, indikator pencapaian kompetensi untuk penilaian, alokasi waktu, dan sumber belajar. Selain silabus, guru juga memiliki lesson plan (Rencana Program Pembelajaran/RPP). Silabus dan lesson plan memiliki perbedaan yaitu jika silabus merupakan rancangan kegiatan belajar mengajar untuk satu tahun ajaran dan diberikan kepada siswa di setiap awal semester baru sedangkan lesson plan (Rencana Program Pembelajaran/RPP) merupakan rancangan kegiatan belajar mengajar untuk satu minggu yang hanya dimiliki guru dan tidak diberikan kepada siswa.Di 
Almaktabah Vol. 5, No. 1, Juni 2020

dalam lesson plan, terdapat kegiatan kunjungan ke perpustakaan sekolah. Kegiatan ini sudah didiskusikan oleh guru dan kepala perpustakaan sekolah SD Negeri Krandon 1 Tegal. Pustakawan membuat jadwalkunjungperpustakaan dari hari Senin hingga Sabtu berdasarkan urutan kelas terkecil yaitu kelas 1 sampai dengan kelas terbesar yaitu kelas 6 sehingga tidak akan terjadi kunjungan perpustakaan secara bersamaan. Kegiatan yang biasanya dilakukan di perpustakaan antara lain adalah belajar bersama di perpustakaan, mencari bahan untuk tugas pelajaran, pengayaan (remedial) pelajaran, dan lainlain.Kunjungan perpustakaan ini sangat diminati oleh para guru karena mereka dapat mengajak siswanya untuk memanfaatkan perpustakaan sekolah sebagai salah satu sumber belajar.

Berdasarkan latar belakang serta identifikasi masalah yang didapat, maka penulis merumuskan masalah secara umum adalah: "Bagaimana Pemanfaatan Perpustakaan sebagai Sumber Belajar Bahasa Indonesia di SDN Krandon 1 Tegal ?". Penelitian ini dilakukan untuk mengetahui Mengetahui bagaimana hubungan antara pemanfaatan perpustakaan sebagai sumber belajar dengan hasil belajar siswa pada mata pelajaran Bahasa Indonesia di SDN Krandon 1 Tegal.Penelitian ini memberi gambaran yang lebih jelas tentang hubungan antara pemanfaatan perpustakaan sebagai sumber belajar dengan hasil belajar siswa pada mata pelajaran Bahasa Indonesia di SDN Krandon 1 Tegal.

\section{TINJAUAN PUSTAKA}

\section{Pemanfaatan Perpustakaan Sekolah}

Menurut pendapat Azhar, Perpustakaan merupakan pusat sarana akademis. Perpustakaan menyediakan bahan-bahan pustaka berupa barang cetakan seperti buku, majalah/jurnal ilmiah, peta, surat kabar, karya-karya tulis berupa monograf yang belum diterbitkan, serta bahan-bahan non-cetakan 76 seperti micro-flas, micro-film, foto-foto, film, kaset audio/video, lagu-lagu dalam piringan hitam, rekaman pidato (documenter), dan lain-lain. ${ }^{1}$ Oleh karena itu, perpustakaan dapat dimanfaatkan oleh pelajar, mahasiswa, dan masyarakat pada umumnya untuk memperoleh informasi dalam berbagai bidang keilmuan baik tujuan akademis maupun untuk referensi.

Tujuan perpustakaan menurut Sutarno, "Tujuan Perpustakaan adalah untuk menyediakan fasilitas dan sumber informasi dan menjadi pusat pembelajaran". 2 Sedangkan menurut Lasa, tujuan perpustakaan adalah sebagai berikut; (1) menumbuhkembangkan minat baca dan tulis, (2) mengenalkan teknologi informasi, (3) membiasakan akses informasi secara mandiri, dan (4) memupuk bakat dan minat.

Berdasarkan pendapat dan teori diatas dapat dinyatakan bahwa, pemanfaatan perpustakaan sekolah merupakan suatu proses, perbuatan, usaha atau upaya memanfaatkan perpustakaan sekolah secara optimal guna menunjang proses belajar mengajar agar lebih efektif dan maksimal sehingga dapat membantu tercapainya tujuan pendidikan yang diselenggarakan oleh sekolah.

\section{Hasil Belajar Bahasa Indonesia}

Setiap siswa yang melakukan kegiatan belajar akan selalu ingin mendapatkan dan mengetahui hasil dari belajarnya selama ini. Untuk dapat mengetahui hasil dari proses belajar tersebut, dapat dilakukan dengan cara menyelenggarakan evaluasi kepada siswa sehingga guru dapat memberikan penilaian terhadap hasil belajar yang telah dilakukan oleh siswa.

\footnotetext{
1 Arsyad, Azhar. (2007). Media Pembelajaran. Penerbit : Jakarta. PT. Raja. Grafindo Persada.

${ }^{2}$ Sutarno NS. 2006. Perpustakaan dan Masyarakat. Jakarta: Sagung Seto
} 


\section{Sri Mulyati, Yuliana Purma Sari, Wahyu Asriyani, Muhammad Rasyid Ridho, Yoandini Saputri}

Pemanfaatan Perpustakaan Sekolah Sebagai Sumber Belajar Bahasa Indonesia

Pengertian Hasil Belajar menurut Purwanto $(2011: 46)^{3}$ hasil belajar adalah perubahan perilaku peserta didik akibat belajar. Perubahan perilaku disebabkan karena dia mencapai penguasaan atas sejumlah bahan yang diberikan dalam proses belajar mengajar. Lebih lanjut lagi ia mengatakan bahwa hasil belajar dapat berupa perubahan dalam aspekkognitif, afektif dan psikomotorik. Sejalan dengan pendapat tersebut Sudjana $(2003: 3)^{4}$ mengemukakan bahwa hasil belajar adalah perubahan tingkah laku yang mencakup bidang kognitif, afektif, dan psikomotorik yang dimiliki oleh siswa setelah menerima pengalaman belajar. Selain itu, Hamalik (2003:155) ${ }^{5}$ mengungkapkan bahwa hasil belajar adalah sebagai terjadinya perubahan tingkah laku pada diri seseorang yang dapat di amati dan di ukur bentuk pengetahuan, sikap dan keterampilan. Perubahan tersebut dapat di artikan sebagai terjadinya peningkatan dan pengembangan yang lebih baik sebelumnya yang tidak tahu menjadi tahu.

Berdasarkan pendapat-pendapat yang telah dipaparkan di atas, maka dapat dikemukakan bahwa hasil belajar adalah suatu perubahan perilaku yang terjadi pada diri peserta didik baik pengetahuan, sikap dan keterampilannya serta perubahan tersebut akan menimbulkan peningkatan dan pengembangan yang lebih baik pada diri peserta didik.

\section{METODE}

Penelitian ini menggunakan jenis penelitian hukum empiris dengan pendekatan kualitatif. Pengambilan sumber data penelitian ini menggunakan teknik "purpossive sampling" dengan

\footnotetext{
${ }^{3}$ Purwanto. 2011. Evaluasi Hasil Belajar. Yogyakarta: Pustaka Pelajar

${ }^{4}$ Nana Sudjana. (2003). Penilaian Hasil Proses Belajar Mengajar. Cetakan ketujuh. Bandung : PT Remaja Rosdakarya

${ }^{5}$ Hamalik, Oemar. (2003). Proses Belajar Mengajar. Jakarta: PT. Bumi Aksara. Hidayati, dkk
}

subjek yang diteliti adalah siswa kelas 3, 4, 5, dan 6 yang karena cara pikir dan kematangan psikologis mereka sudah lebih baik dalam dengan tujuan untuk menghilangkan kemungkinan terjadinya "kemencengan" (bias). Sedangkan objeknya adalah kegiatan-kegiatan yang dilakukan di perpustakaan dalam rangka pemanfaatan Perpustakaan Sekolah SD Negeri Krandon 1 Tegal sebagai penunjang kegiatan belajarmengajar terutama mata pelajaran Bahasa Indonesia

Penelitian ini dilakukan selama lima bulan yaitu, sejak bulan Oktober 2019 sampai dengan bulan Februari 2019. Penelitian bertempat di SD Negeri Krandon 1 Tegal yang beralamat di Jalan DR. Cipto Mangunkusumo No.12, Krandon-Kota Tegal.Untuk pengumpulan data, penulis melakukan studi literature dokumen yang relevan dengan penelitin, observasi partisipan pasif dengan mengamati kegiatan yang berkaitan dengan pemanfaatan perpustakaan sekolah tetapi tidak ikut terlibat dalam kegiatan tersebut, wawancara dengan pihak yang terkait dengan penelitian ini, dan dokumentasi sumber tercetak maupun elektronik.

Data yang telah dikumpulkan selanjutnya diolah dan kemudian dianalisis. Langkah-langkah dalam mengolah data kualitatif, yaitu Membuat transkrip hasil rekamanwawancara, transkrip hasil wawancara yang diperoleh dari siswa kelas 3, 4, 5 dan 6, guru dan pihak internal sekolah di SD Negeri Krandon 1 Tegal tersebut ditelaah dan kemudian direduksi sesuai dengan objekpenelitian.Hasil wawancara tersebut dikaitkan dengan hasil observasi serta disesuaikan dengan tinjauan literatur sebagai teori yang menguatkan dan melemahkan argumenpenulis. Tahap terakhir adalah kesimpulan dari hasil data-data yang diperoleh dari penelitiantersebut. 
Almaktabah Vol. 5, No. 1, Juni 2020

\section{HASIL DAN PEMBAHASAN}

Berdasarkan hasil penelitian yang dilakukan peneliti mengenai peran perpustakaan sekolah sebagai sumber belajar Bahasa Indonesia di SD Negeri Krandon 1 Tegal dan dengan menganalisa serta meninjau langsung fakta-fakta di lapangan bahwasannya perpustakaan di SD Negeri Krandon 1 Tegal memiliki peran yang signifikan sebagai penunjang pembelajaran, baik dari sarana prasarana, pelayanannya, serta referensi buku yang ada. Apakah sarana prasarana, pelayanan, serta buku-buku referensi Bahasa Indonesia di perpustakaan tersebut menunjang pembelajaran peserta didik di sekolah tersebut sehingga terjawablah peran dari perpustakaan yang baik itu seperti apa.

Perpustakaan SD Negeri Krandon 1 Tegal memiliki kepala perpustakaan yang bertugas sebagai pengurus pelayanan perpustakaan, perencanaan pengembangan, memelihara dan perbaikan pustaka, menyusun tata tertib.Layanan pengadaan/pengelolaan sudah mencakup layanan teknis dan layanan teknologi informasi dan komunikasi yang bertugas untuk mendata buku keluar masuk perpustakaan. Layanan pemustaka yang dirangkap oleh sekretaris bertugas untuk melayani peminjaman buku, mengatur dan memelihara ruangan, mengklasifikasi buku, dan lain- lain. Kemudian layanan teknologi informasi dan komunikasi bertugas untuk memberikan pelayanan berupa layanan teknologi seperti pengisian data peminjaman buku yang sudah yang sudah memakai komputer. Dari uraian tersebut dapat dikatakan bahwa SD Negeri Krandon 1 Tegal adalah sekolah yang sudah menerapkan teknologi dalam bidang perpustakaan. Perpustakaan SD Negeri Krandon 1 Tegal hanya memiliki 1 lulusan Ilmu Perpustakaan sedangkan untuk anggota yang lainnya yaitu sarjana pendidikan. Sehingga dari segi struktur organisasi perpustakaan SD Negeri Krandon 1 Tegal kurang baik.
Perpustakaan SD Negeri Krandon 1 Tegal sudah mencantumkan visi, misi, tujuan yang baik, di mana visi perpustakaan SD Negeri Krandon 1 Tegal sudah mengacu pada visi sekolah yang merupakan lembaga induknya. Misi perpustakaan SD Negeri Krandon 1 Tegal menyediakan informasi dan ide yang merupakan fondasi agar berfungsi secara baik, menyediakan sarana bagi peserta didik agar mampu belajar, dan mengembangkan daya pikir agar dapat hidup sebagai warga negara yang bertanggungjawab.

Tata tertib perpustakaan sekolah harus dibuat secara singkat, jelas, dan sederhana sehingga mudah dimengerti oleh semua pengunjung. Masalah-masalah yang harus dicantumkan dalam tata tertib meliputi: sifat dan status perpustakaan sekolah, keanggotaan perpustakaan sekolah, bahan-bahan pustaka yang tersedia, sanksi dan hukuman bagi pelajar, iuran bagi setiap anggota, sistem penyelenggaraan, dan waktu pelayanan atau jam buka. Perpustakaan di SD Negeri Krandon 1 Tegal sudah mencantumkan poin pertama yaitu status perpustakaan sekolah di mana sama-sama milik pemerintah, yang kedua keanggotaan perpustakaan jelas sekolah tersebut yaitu peserta didik, guru, dan semua staf karyawan sekolah tersebut sebagai anggota Poin ketiga mencantumkan masalah mengenai peminjaman bahan-bahan pustaka yang tersedia, di SD Negeri Krandon 1 Tegal sudah sama-sama mencantumkan mengenai peminjaman buku. Poin ke empat sekolah tentunya sudah menerapkan sanksi-sanksi dan hukuman bagi peserta didik yang melanggar tata tertib dan sebagainya. Poin kelima sekolah sudah mencantumkan sistem penyelenggaraan perpustakaan di sekolah. Waktu pelayanan atau jam buka juga sudah dicantumkan oleh sekolah. Berdasarkan uraian di atas bahwasannya sekolah di SD Negeri Krandon 1 Tegal sudah baik dalam penerapannya, karena sekolah sudah mencantumkan masalah-masalah yang harus dicantumkan dalam tata tertib. 
Sri Mulyati, Yuliana Purma Sari, Wahyu Asriyani, Muhammad Rasyid Ridho, Yoandini Saputri

Pemanfaatan Perpustakaan Sekolah Sebagai Sumber Belajar Bahasa Indonesia

Tabel 1 masukkan hasil pembahasan Jadwal Pelayanan Perpustakaan

\begin{tabular}{|c|l|l|l|}
\hline No. & \multicolumn{1}{|c|}{ Hari } & $\begin{array}{l}\text { Waktu } \\
\text { (WIB) }\end{array}$ & \multicolumn{1}{|c|}{ Ket. } \\
\hline 1. & $\begin{array}{l}\text { Senin - } \\
\text { Kamis }\end{array}$ & $\begin{array}{l}07.30- \\
12.30\end{array}$ & $\begin{array}{l}\text { Istirahat } \\
1 \text { dan 2 }\end{array}$ \\
\hline 2. & Jum'at & $07.30-$ & Istirahat 1 \\
& & 07.00 & \\
\hline 3. & Sabtu & 12.00 & Istirahat 1 \\
& & dan 2 \\
\hline
\end{tabular}

Sumber : Perpustakaan SDN Krandon 1 Tegal

Sarana dan prasarana di perpustakaan SD Negeri Krandon 1 Tegal dari kelengkapannya terdapat beberapa sarana dan prasarana yang belum ada atau belum memadai. Seperti misalnya rak buku hanya terdapat 12 saja padahal standarnya 15 buah. Sehingga masih banyak buku yang berserakan di lantai dan peserta didik pun kesulitan mencari buku. Gedung perpustakaan di sini pun hanya berukuran $15 \times 20 \mathrm{~m}^{2}$ sehingga ketercukupan murid pun kurang terpenuhi. Referensi buku Bahasa Indonesia di sini pun masih sedikit sehingga akibatnya peserta didik pun kurang termotivasi untuk ke perpustakaan. Tempat tas atau barang pun tidak ada sehingga pengunjung meletakkannya di lantai luar gedung. Masih banyak kekurangan-kekurangan yang lainnya sehingga perpustakaan di SD Negeri Krandon 1 Tegal ini perlu adanya pembaharuan.

Tabel 2

Statistik Data Pengunjung Perpustakaan SDN Krandon 1 Tegal (Bulan Juli - September 2019)

\begin{tabular}{|c|c|c|}
\hline No & Bulan & Pengunjung \\
\hline 1 & Juli & 278 \\
\hline 2 & Agustus & 287 \\
\hline
\end{tabular}

\begin{tabular}{|c|c|c|}
\hline 3 & September & 973 \\
\hline \multicolumn{2}{|c|}{ Sumber: Perpustakaan SD Negeri Krandon 1 Tegal } \\
\hline
\end{tabular}

Segi pelayanannya perpustakaan di SD Negeri Krandon 1 Tegal sudah cukup baik. Peminjaman buku dan pengembalian buku peserta didik harus mengikuti prosedur yang sudah ada. Di perpustakaan SD Negeri Krandon 1 Tegal sudah menerapkan library senayan yaitu suatu penerapan teknologi oleh perpustakaan, jadi di perpustakaan SD Negeri Krandon 1 Tegal mulai dari pendataannya sudah melalui komputer/online Sedangkan perpustakaan di SD Negeri Krandon 1 Tegal belum menerapkan (masih manual). Bagi peserta didik yang telat memulangkan buku atau merusak buku akan di denda atau di kenakan sanksi yang telah ditentukan oleh perpustakaan tersebut.

Daftar peminjaman buku Bahasa Indonesia di SD Negeri Krandon 1 Tegal bervariasi paling banyak buku dipinjam pada tahun 2015 bulan september sebanyak 81 buku. di perpustakaan SD Negeri Krandon 1 Tegal karena sudah menggunakan SLiMS sehingga ada data-data yang tidak tercantum karena ada kesalahan teknis dengan tidak terdaftarnya atau kurangnya peminjaman buku biologi pada bulan tertentu. Sedangkan di SD Negeri Krandon 1 Tegal banyak data yang hilang sehingga tidak diketahui data pengunjung setiap harinya dan hanya beberapa bulan saja yang terdaftar. 
Almaktabah Vol. 5, No. 1, Juni 2020

Tabel 3

Statistik Data Buku yang Dipinjam Bulan Juli - September 2019

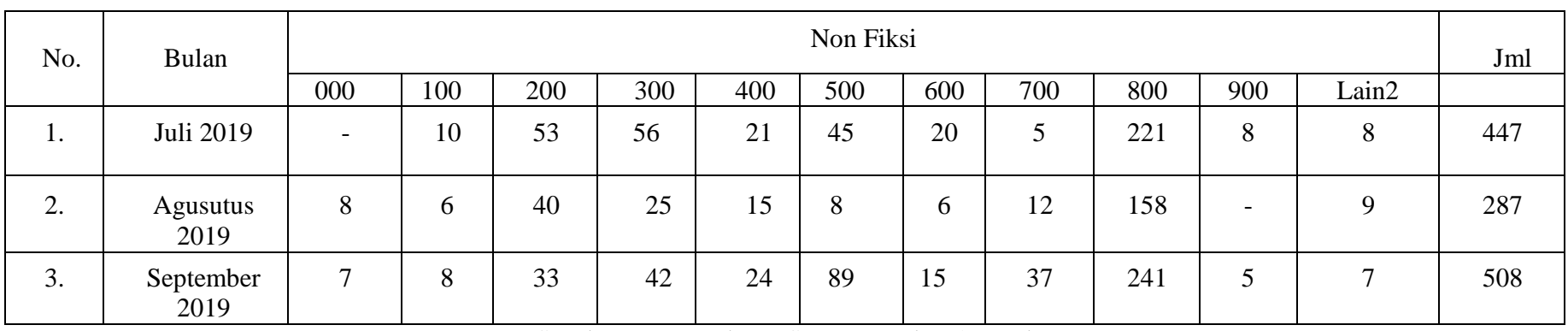

Sumber:Perpustakaan SDN Krandon 1Tegal

Berdasarkan tabel 3, data buku yang sering dipinjam pada bulan Agustus-September buku-buku dengan angka klasifikasi 800 (kesusasteraan) yang berupa buku-buku cerita, dongeng, maupun bukubuku pelajaran bahasa dan sastra. Hal ini, menunjukkan bahwa peminjaman buku diminati.

Penelitian yang dilakukan oleh Rizki Febriani yang berjudul "Pemanfaatan Perpustakaan Sekolah sebagai Sumber Belajar Peserta didik di SMP”. Hasil dari penelitian ini yaitu pemanfaatan perpustakaan telah dimanfaatkan oleh peserta didik dengan baik terbukti dengan perpustakaan sekolah di SMP Negeri 3 Sungai Raya Kabupaten Kubu Raya memiliki fungsi edukasi dengan adanya buku fiksi dan nonfiksi serta fungsi rekreatif dengan tersedianya buku fiksi. Frekuensi kehadiran peserta didik ke perpustakaan sekolah dari bulan juli hingga oktober adalah $76 \%$. Hal ini memberikan gambaran bahwa pemanfaatan perpustakaan telah dimanfaatkan denganbaik.

Penelitian yang dilakukan oleh Darmono yang berjudul "Pengembangan Perpustakaan Sekolah Sebagai Sumber Belajar”. Penelitian ini menunjukkan Keberadaan perpustakaan sekolah perlu ditangani secara baik dan memadai. Untuk itu diperlukan kemauan dari berbagai pihak untuk mengembangkannya yaitu penentu kebijakan pada tingkat departemen, tingkat daerah, tingkat sekolah (kepala sekolah, guru, dan pengelola perpustakaan).
Perpustakaan SD Negeri Krandon 1 Tegal berada di tengah-tengah, sehingga mudah di jangkau olehpengunjung.

Penelitian yang dilakukan oleh Mulyadi SK dan Febriana Primasari yang berjudul "Implementasi Perpustakaan Sekolah Sebagai Sumber Belajar dalam Meningkatkan Prestasi Belajar Sisiwa”. Hasil dari penelitian ini adalah perpustakaan sekolah sebagai sumber belajar peserta didik di SDN Tunggulsari 1 No. 72 Laweyan belum bisa dimanfaatkan untuk meningkatkan prestasi peserta didik. Hal itu di karenakan manfaat perpustakaan belum maksimal di rasakan bagi peserta didik. Perpustakaan sekolah akan lebih menarik jika pihak sekolah memberikan perhatian yang maksimal untuk menjadikan perpustakaan sebagai taman baca peserta didik.

Berdasarkan hasil wawancara kepada kepala perpustakaan SD Negeri Krandon 1 Tegal yaitu ibu Eni Hastuti M.Pd menurutnya perpustakaan di SD Negeri Krandon 1 Tegal ini sudah layak sebagai sumber belajar atau sumber informasi bagi peserta didik, guru, serta staf lain yang membutuhkannya. Pustakawan di SD Negeri Krandon 1 Tegal dan pernah mengikuti orientasi atau pembekalan kepada pengelola perpustakaan dengan bekerjasama Badan Arsip dan Perpustakaan Daerah Kota Tegal tepatnya pada tahun 2014. Selain referensi buku yang lengkap perpustakaan SD Negeri Krandon 1 Tegal juga 


\section{Sri Mulyati, Yuliana Purma Sari, Wahyu Asriyani, Muhammad Rasyid Ridho, Yoandini Saputri}

Pemanfaatan Perpustakaan Sekolah Sebagai Sumber Belajar Bahasa Indonesia

menyediakan sumber info lain seperti jurnal dan CD pembelajaran. Perpustakaan ini juga pernah mengadakan lomba untuk peserta didik atau lomba per kelas yaitu "satu buku1000cinta" yaitu buku fiksi, terkumpul 1000 buku lebih dan kelas yang paling banyak mengumpulkan buku mendapatkan hadiah.

Hasil wawancara kepada kepala perpustakaan SD Negeri Krandon 1 Tegal yaitu bapak Syaiful Anwar S.Pd menurutnya perpustakaan sudah layak dalam menunjang proses pembelajaran yaitu sebagai sumber informasi. Petugas perpustakaan dan pustakawan pernah mengikuti orientasi atau pembekalan selama 1 hari di Kota Tegal tepatnya di Badan Arsip dan Perpustakaan Daerah Kota Tegal pada tahun 2012. Menurutnya perpustakaan SD Negeri Krandon 1 Tegal sudah cukup lengkap dilihat dari sarana dan prasarana hanya saja di perpustakaan ini tidak ada papan tulis sehingga akan diajukannya papan tulis, di tambah perpustakaan SD Negeri Krandon 1 Tegal sudah memiliki cctv sehingga mengurangi resiko yang tidak diinginkan, dan menurutnya pun referensi buku di sini sudah lengkap. Perpustakaan SD Negeri Krandon 1 Tegal tidak pernah mengadakan perlombaan bagi peserta didik sehingga tahun ini akan diadakannya reward.

Hasil wawancara kepada guru biologi di SD Negeri Krandon 1 Tegal kepada ibu Dra. Hj Yuniarti menurutnya peran perpustakaan di SD Negeri Krandon 1 Tegal sangat baik dalam menunjang pembelajaran khususnya Bahasa Indonesia, referensi buku di sini sangat lengkap, fasilitas yang ada sangat membantu peserta didik, perpustakaan di sini sudah menggunakan teknologi jadi semua akses di perpustakaan sudah menggunakan system online. Kekurangan perpustakaan di sini menurutnya adalah tidak adanya cctv sehingga petugas atau pengelola perpustakaan harus berhati-hati agar tidak terjadi hal yang tidak diinginkan. Untuk memotivasi peserta didik agar belajar di perpustakaan yaitu dengan memberikan tugas-tugas yang mengharuskan peserta didik mencari informasi di perpustakaan.

Hasil wawancara kepada salah satu guru biologi di SD Negeri Krandon 1 Tegal kepada ibu Dra. Eny Supriyati bahwa menurutnya peran perpustakaan di SD Negeri Krandon 1 Tegal cukuplah baik dalam menunjang pembelajaran, dilihat dari segi sarana dan prasarana, referensi buku Bahasa Indonesia di perpustakaan pun sudah lengkap dan materi yang ada di buku sangat membantu peserta didik dan guru dalam menunjang pembelajaran di kelas. Kekurangan perpustakaan di sini sebagai sumber belajar Bahasa Indonesia menurutnya adalah tidak adanya referensi sumber belajar Bahasa Indonesia selain buku misalnya seperti pembelajaran melalui CD/DVD. Untuk memotivasi peserta didik membaca/belajar di perpustakaan dengan cara memberikan tugas-tugas yang mengharuskan peserta didik belajar di perpustakaan, sehingga termanfaatkanlah sumber belajar Bahasa Indonesia di perpustakaan.

Berdasarkan hasil observasi, wawancara dan analisa di atas maka dapat di katakan perpustakaan di SD Negeri Krandon 1 Tegal memiliki peran yang baik dalam menunjang pembelajaran Bahasa Indonesia. Perpustakaan di SD Negeri Krandon 1 Tegal dari segi sarana dan prasarana sudah memenuhi standar perpustakaan hanya ada beberapa sarana yang kurang lengkap. Sistem pelayanannya perpustakaan SD Negeri Krandon 1 Tegal pustakawan di perpustakaan tersebut sangat ramah dalam melayani pengunjung sehingga membuat pengunjung tidak sungkan bertanya kepada pustakawan, perpustakaan SD Negeri Krandon 1 Tegal juga sudah menerapkan sistem pelayanan tertutup yakni pada tahun 2014 mengadakan lomba kepada peserta didik antar kelas. Referensi buku biologi di SD Negeri Krandon 1 
Almaktabah Vol. 5, No. 1, Juni 2020

Tegal juga sangat lengkap sekali sehingga memudahkan peserta didik untuk mengerjakan atau menyelesaikan tugas-tugas yang diberikan oleh guru, hal itu bisa dilihat banyaknya peminjaman buku biologi di perpustakaan SD Negeri Krandon 1 Tegal.

Di samping itu Perpustakaan SD Negeri Krandon 1 Tegal juga masih banyak kekurangankekurangan yang harus dilengkapi dan dibenahi oleh perpustakaan tersebut, sebagai contoh perpustakaan tersebut padahal sudah menerapkan SLiMS (senayan library management system) yang seharusnya perpustakaan tersebut sudah di lengkapi CCTV dan pada kenyataannya tidak ada. Berdasarkan hasil wawancara kepada kepala perpustakaan dan guru Bahasa Indonesia bahwa perpustakaan SD Negeri Krandon 1 Tegal sudah layak karena sudah memenuhi standar perpustakaan dan dapat menjadi contoh perpustakaan Sekolah Dasar di seluruh kota Tegal

Perpustakaan SD Negeri Krandon 1 Tegal meskipun sudah baik dalam penerapannya tetapi sarana dan prasarananya masih kurang lengkap, referensi buku biologi yang sedikit, sehingga peminjaman buku biologi di SD Negeri Krandon 1 Tegal sangat sedikit jumlahnya. Perpustakaan SD Negeri Krandon 1 Tegal pun dalam pendataannya masih menggunakan sistem manual belum menerapkan SLiMS. Akan tetapi perpustakaan di SD Negeri Krandon 1 Tegal tersebut dalam sistem pelayananya sangat ramah sehingga pengunjung pun tidak sungkan untuk belajar diperpustakaan.

\section{KESIMPULAN}

Berdasarkan hasil penelitian serta menganalisis data-data yang diperoleh maka dapat disimpulkan bahwa perpustakaan di SD Negeri Krandon 1 Tegal sangat baik dalam menunjang pembelajaran Bahasa Indonesia, dari segi sarana dan prasarana sudah memenuhi standar perpustakaan hanya ada beberapa sarana yang kurang lengkap. Referensi buku Bahasa Indonesia di Perpustakaan SD Negeri Krandon 1 Tegal cukup lengkap sehingga memudahkan peserta didik untuk mengerjakan atau menyelesaikan tugas-tugas yang diberikan oleh guru, hal itu bisa dilihat banyaknya peminjaman buku Bahasa Indonesia di perpustakaan SD Negeri Krandon 1 Tegal.Perpustakaan SD Negeri Krandon 1 Tegal juga sudah menerapkan sistem pelayanan tertutup yakni pada tahun 2014 mengadakan lomba kepada peserta didik antar kelas dan sudah menerapkan SLiMS (senayan library management system). Pemanfaatan Perpustakaan SD Negeri Krandon 1 Tegal sebagai sarana pendukung proses pembelajaran mata pelajaran Bahasa Indonesia cukup baik sehingga diharapkan hasil belajar siswa pun akan baik.

Peneliti menyarankan agar guru memberikan tugas-tugas yang menghasurkan peserta didik mencari sumber informasi di perpustakaan sekolah, pustakawan dapat mengelola ruang perpustakaan semenarik mungkin agar siswa merasa nyaman saat berada di perpustakaan, dan sekolah dapat mengajukan sarana prasarana yang belum lengkap sehingga pengunjung perpustakaan lebih terfasilitasi dengan sarana yang ada. Bagi peneliti lain, pengambilan data pengamatan atau observasi harus benar-benar teliti agar didapat data yang valid.

\section{DAFTAR PUSTAKA}

Arikunto, S. (1998). Prosedur Penelitian: Suatu Pendekatan Praktik. Jakarta: Rineka Cipta.

Aranda, K. (n.d.). Pemanfaatan Perpustakaan Sekolah: Studi Kasus Peran Guru di SMA Lazuardi Global Islamic School, Depok. Retrieved January 20, 2011, from http://www.lontar.ui.ac.id/ 


\section{Sri Mulyati, Yuliana Purma Sari, Wahyu Asriyani, Muhammad Rasyid Ridho, Yoandini Saputri}

Pemanfaatan Perpustakaan Sekolah Sebagai Sumber Belajar Bahasa Indonesia

Badudu, J. S., \& Zain, S. M. (1994). Kamus umum bahasa Indonesia. Jakarta: Pustaka Sinar Harapan.

Bafadal, I. (2009). Pengelolaan perpustakaan sekolah. Jakarta: Bumi Aksara.Basuki, S. (1993). Pengantar ilmu perpustakaan. Jakarta: PT Gramedia Pustaka Utama.

Balai Pustaka. (1994). Kamus Besar Bahasa Indonesia. Jakarta.

Darmono. (2007). Pengelolaan Perpustakaan Sekolah. Jakarta: Grasindo.

Dewi, H. D. R. (2006). Coursepack on teacher librarianship: kumpulan artikel tentang perpustakaan sekolah/guru pustakawan. Yogyakarta: Jurusan Ilmu Perpustakaan dan Informasi, Fakultas Adab, UIN Sunan Kalijaga.

Effendi, M. (2010). Pemanfaatan Koleksi Buku Teks Pelajaran Pada Perpustakaan Sekolah Dalam Kegiatan Belajar Mengajar Siswa Kelas VIII MTs Negeri Karangawen

Demak.Skripsi.Universitas Diponegoro, Semarang.

Faturrohman, P., \& Sutikno, M. S. (2011). Strategi Belajar Mengajar. Bandung: PT Refika Aditama.

HS, Lasa. (2007). Manajemen Perpustakaan Sekolah. Yogyakarta: Pinus Book.

IFLA.(n.d.).Perpustakaan Sekolah dalam Pengajaran dan Pembelanjaran untuk Semua.Retrieved January 20, 2011, from http://www.ifla.org./VII/s11/manifesto/id.htm.

Jackson. (2006). Manajemen Sumber Daya Manusia. Jakarta : Salempa Empat.

Kencana, A. N. (n.d.). Pengolahan Koleksi di Dok. Pus.Prog. TVRI. Retrieved January 20, 2011, from http://www.lontar.ui.ac.id/

Meleong, L. J. (2000). Metologi penelitian kualitatif. Bandung: PT Remaja Rosdakarya.

Menteri Pendidikan Nasional.Pedoman Pelaksanaan Kinerja Guru. Jakarta.

Menteri Pendidikan Nasional.(2008). Peraturan Menteri Pendidikan Indonesia Nomor 25 Tahun 2008 Tentang Standar Tenaga Perpustakaan Sekolah/Madrasah. Jakarta.
Menteri Pendidikan Nasional. (2010). Peraturan Menteri Pendidikan Indonesia Nomor 35 Tahun 2010 Tentang Petunjuk Teknis Pelaksanaan Jabatan fungsional Guru dan Angka Kreditnya. Jakarta.

Menteri Pendidikan Nasional.Undang-Undang Nomor 2 Tahun 1989 Tentang Sistem Pendidikan. Jakarta.

Menteri Pendidikan Nasional.Undang-Undang Nomor 19 Tahun 2005 Tentang Standar Nasional Pendidikan. Jakarta.

Menteri Pendidikan Nasional.Undang-Undang Nomor 20 Tahun 2003 Tentang Sistem Pendidikan Nasional. Jakarta.

Musa, M., \& Nurfitri, T. (1998). Metodologi Penelitian. Purwokerto: Universitas Jedral Soedirman.

Pendit, P. L. (2003). Penelitian ilmu perpustakaan dan informasi: suatu pengantar diskusi epistemologi dan metodologi. Jakarta: Jurusan Ilmu Perpustakaan-Fakultas Sastra, Universitas Indonesia (JIP-FSUI).

Perpustakaan Nasional. (1994). Perpustakaan Sekolah: Petunjuk Untuk membina, Memakai, dan Memelihara Perpustakaan di Sekolah. Jakarta: Perpustakaan Nasional RI.

Ray, C. (1981). Handbook Teacher - Librarians. London: Commonwealth Secretariat.

Rosidi, I. (n.d.). membaca cepat. Retrieved August 21, 2011, from https://guruumarbakri.blogspot.com/2009/05/membacacepat.html

Rostina, L. (2006).Perilaku Pencarian Informasi Tenaga Kesehatan: Studi KAsus Tentang Perilaku Penemuan Informasi Tenaga Kesehatan pada Perpustakaan Rumah Sakit Pertamina (RSPP). Tidak diterbitkan.

Sarjono. (2007).Pemanfaatan Perpustakaan Lembaga Penjamin Mutu Pendidikan Jawa Tengah Dalam Upaya Meningkatkan Kinerja Widyaiswara. Skripsi. Semarang: Universitas Diponegoro.

SD Negeri Krandon 1.KTSP SD Negeri Krandom 1, Kota Tegal. Tegal.

Soeatminah. (1992). Perpustakaan, kepustakawanan dan pustakawan. Yogyakarta: Kanisius.

Soedibyo, N. (1987). Pengelolaan Perpustakaan Jilid 1. Bandung: Penerbit Alumni. 
Almaktabah Vol. 5, No. 1, Juni 2020

Sugiyono. (2008). Metode penelitian bisnis.

Bandung: Alfabeta.

Suharto, B. (2006). Jangan Pulang Sebelum Menang: Kiat Suksea Kehidupan dan Kepemimpinan. Jakarta: Gita Pustaka.

Suwarno, W. (2016). Perpustakaan \& buku: wacana penulisan \& penerbitan. Jogjakarta: Ar-Ruzz Media.

Teacher Librarian: The Journal For School Library Professionals. (n.d.). Retrieved January 12, 2011, from http://teacherlibrarian.com/

Warsita, B. (2008). Teknologi Pembelajaran. Jakarta: Rineka Cipta.

Yusuf, P. M. (2007). Praktis Pengelolaan Perpustakaan Sekolah Dasar. Jakarta: Kencana.

Yusuf, P. M., \& Suhendar, Y. (2005). Pedoman penyelenggaraan perpustakaan sekolah. Jakarta: Prenada Media Group.

Zulaikh, S. R. (n.d.). Peran Guru Pustakawan Dalam Pemberdayaan Perrpustakaan Madrasah IGPM Daerah Yogyakarta. Retrieved October 12, 2010, from http://www.pustakasiana.com/ 